DOI: 10.24234/wisdom.v14i1.306

Lucio GIULIODORI, Aisana BOLDYREVA, Anna BOBUNOVA, Vladislav BORANENKOV, Elena NOTINA

\title{
SURREALISM BETWEEN PSYCHOLOGICAL INVESTIGATION AND ARTISTIC COMMITMENT
}

\begin{abstract}
Deciphering the mysteries of the unconscious was one of the central aims of Surrealists who, in order to achieve this goal, experimented with the most different techniques. The unconscious, displaying the contents that then can be painted, turned to be both a way to embark on inner exploration and a source of creativity.

My paper firstly sheds light onto this marriage of art and psychology which, in Surrealism, harmoniously blended generating a fascinating and fruitful combination between creation and self-creation - art as a tool of self-knowledge and even inner evolution is one of the main consequences.

Lastly, this study examines the surrealist scene today, considering how and why, through the decades, the painters' aims changed and why we should or shouldn't still call them "Surrealists".

Keywords: surrealism, paintings, contemporary art, aesthetics, philosophy of art, psychology, unconscious.

"We do not want to reproduce, we want to produce, like a plant which produces a fruit, directly and not by intermediary. We want to produce directly. Not indirectly."

Hans Arp

\section{An Inner Journey}

At the end of World War I, many of the main characters of Dada gathered in Paris; Picabia, Tzara, Ray, Duchamp and Ernst were among the leading figures. The periodical Littérature set up by Breton and Soupault in collaboration with Aragon was the main laboratory whose experiments would then later lead to Sur-

realism itself - which was partly inspired by the "metaphysical investigations" carried out by De Chirico. However, what was Surrealism's main aim? According to Flaminio Gualdoni (2008):

"The objective was still that of total art, i.e. of a wide-ranging artistic attitude that cultivated all means of expression, from poetry to music, from drama to painting, playing down specific techniques and
\end{abstract}


languages in favour of creativity that was linked entirely to the moods of the individual and that chose, on each occasion, the most suitable medium with which to work" (p. 7).

On top of that, surrealists' concerns turned out to be linked with psychology, more precisely with the "discovery" of the unconscious, to which Surrealism owes a great deal. Even though Assagioli thought that this discovery could have been compared to the discovery of a new continent ${ }^{1}$, Massimo Recalcati argues that Freud basically didn't discover the unconscious rather, through his narrative, he invented it (Recalcati, 2007). Taking everything into account, poets, philosophers, artists or mystics who lived much before Freud, in different ways, mentioned or even experienced inner journeys of all kinds "altered states of consciousness" as we would define these involvements today. As a matter of fact, when the walls of consciousness are crossed, we can only find the unconscious - or whatever name we assign it.

According to Fiona Bradley (1997): "Surrealism sought communication with the irrational and the illogical, deliberately disorientating and reorientating the conscious by means of the unconscious" (p. 9). That was exactly its main aim. To achieve this target, the first surrealists used to experiment with the most different techniques, from frottage to automatic writing, from assemblage to cadavre exquis, from dripping to hypnosis and, last but not least, drugs itself. As Dorothea Eimert (2013) states:

"Surrealism made use of the experiences of the others in the spheres of unsettling

1 "The importance of the discovery of the unconscious, has been compared to that of America, of a new continent. One can even compare it to the revolution caused by the substitution of the geocentric conception with that heliocentric" (Assagioli, 1993, p. 17. My translation). dream reality and the unconscious. At first, it was the writers Paul Éluard and André Breton, who, having joined together in 1921 in order to enrich their art, sought to stage dreams, visions, uncontrolled associations and experiences of intoxication. It was known that in the $19^{\text {th }}$ century, writers like Stéphane Mallarmé used drugs to broaden their senses in order to open up new dimensions for their writing" (p. 104).

They were literally looking for another surreal - dimension:

"The marvellous was thought to occur naturally, in spaces where the curse of reason had yet to penetrate: in childhood, madness, sleepiness and drug-induced hallucination; in so-called "primitive" societies whose members were thought to be closer to their instincts than to the learned sophistication of "civilisation"; and, crucially, in dreams, the conditions of which the painters attempted to reproduce"(Eimert, 2013, p. 9).

Summing up, René Breton (1969) beautifully defines Surrealism as a way into a mental world of endless possibilities, "a certain point of the mind at which life and death, the real and the imagined, past and future, the communicable and the incommunicable, high and low cease to be perceived as contradictions" (pp. 123-124).

Aragon is even more precise concerning surrealists' perception of reality, and the quotation is not brief, nevertheless worth being mentioned:

"First of all, each of us regarded himself as the object of a special disturbance struggled against this disturbance. Soon its nature was revealed. Everything occurred as if the mind, having reached this crest of the unconscious, had lost the power to recognize its position. In it subsisted images that assumed form, became 
the substance of reality. They expressed themselves according to this relation, as a perceptible force. They thus assumed the characteristics of visual, auditive, tactile, hallucinations. We experienced the full strength of these images. We have lost the power to manipulate them. We had become their domain, their subjects. In bed just before falling asleep, in the street, with eyes wide open with all the machinery of terror, we held out our hand to phantoms..." (Nadeau, 1989, p. 46).

Aragon died in 1897, yet those phantoms are still the main characters in contemporary Surrealism, a movement which never really died. Uppermost pillars such as Leonora Carrington, Leonor Fini, Paul Delvaux and René Magritte laid the foundations for an astounding artistic phenomenon which undoubtedly and ineluctably, is a far cry from running its course, rather the issues it has raised remain central to current debates.

Painters are still involved in decoding the mysteries of something which, undeniably, is still deeply cagey and mysterious: the unconscious indeed.

\section{Dreaming, Creation and Self-Creation}

As far as psychologists' commitment is concerned, a final definition of the unconscious is still yet to come.

Moreover, this is a hard problem to tackle as the object of investigation is indeed invisible to the five senses, and as such, it can't be analysed by using the mechanist-scientist model.

However, if science has not yet yielded any results $^{2}$, art (Surrealism) carves itself out quite a

2 The mechanist model will never manage to decode the unconscious, that is why Wolfgang Pauli hoped physics and psychology could meet, giving birth to a new language able to describe the absurdity of the significant role in displaying the unconscious landscapes. Among the various techniques tested by surrealists, dreaming is certainly the main one as it is the most powerful ${ }^{3}$. Dreaming does open the door to the abyss of the unconscious, and this is precisely what surrealists were/are looking for: deciphering and painting it through dreaming.

As Mary Ann Caws (2010) puts it:

"Dream is, of course, commonly considered as the peak of the unconscious mind's experience, and a resource for the conscious analysis of that experience. The opening up of the field of possibilities was never more exciting to the group than in dream phenomena, whether interpreted collectively or singly. Far beyond the dull colours of the real, as the young Surrealists perceived them, stretched this glorious uncontrollable openness, as far as the mind could reach" (p. 20).

Surrealists always considered dreaming as an immense source of knowledge:
"Why should we not concede to the dream, Breton asks, hat we sometimes re- fuse to attribute to reality - the weight of absolute certainty? Why should we not expect more of the dream than we do from consciousness? Cannot dreams as well be applied to the solution of life's fundamental problems? When confronted

nature of the unconscious. Let us consider his words: "We should now proceed to find a neutral or unitary language in which every concept we use is applicable both to the unconscious and to the matter, in order to overcome this old belief that the unconscious psyche and matter are two separate things" (Teodorani, 2011, p. 82). My translation.

3 As we all know, Sigmund Freud represented one of the main sources of inspiration for surrealists and, to this regard, it's worth mentioning a brief correspondence between him and Breton about a topic which was of interest for the creator of the surrealist Manifesto: the relationship between dreaming and artistic creation.

However, contrary to Breton, Freud was not so interested in that topic and the correspondence ended shortly. 
with the value or importance of the dream state, wakefulness appears to be nothing more than a complete obstacle" (Adonis, 2016, p. 188).

Dreaming in Breton's perspective gains in symbolic weight by virtue of the power of meaning in representation, setting off a chain of multivalent reactions in terms of a radical shift of perception. This perspective still applies today.

Now, focusing on the main point: creativity is for surrealists quite peculiar as it is at the same time the a priori of the final result, the picture itself, and a way to embark on an inner exploration, almost a self-analysis: dreaming is a source of inspiration, but it is also a wide-open window to the inner world, to the hidden sides of the psyche. The main consequence is that in Surrealism, art and psychology, harmoniously blend generating chemistry between creation and self-creation. An inner investigation cannot but produce changes in one's life, at best an effective improvement: if dreaming unveils secret sides or even unresolved problems or complexes, the consequence, it is a stance on the vigil.

The artistic creation, specifically a painting, configures itself as a kind of x-ray, the photo of what exactly one should work on, the oneiric dimension often discloses what the vigil keeps concealed - both dimensions depict two different layers of the same reality. Creativity in Surrealism, clearly merges with a kind of self-knowledge, hence its nobility: Surrealism is not merely art. Surrealism can be seen as a movement pivoted in a principle of change, of improvement: artists, by painting, explore themselves, become themselves, by creating, they create themselves.

To the question: Can we consider art as a tool of inner evolution somehow? The contemporary surrealist painter Steven Kenny says:
'Yes, but that's each artist's choice. For some, it is an aid to psychological, intellectual, and spiritual development; for others, art is simply something they do to make a living. I have learned a lot about myself through my work over the years. The fact that each painting is a new beginning forces me to reconsider all that I know. I struggle not to repeat myself and to discover something new with each painting". ${ }^{4}$

No surprise, his images, as is typical among surrealists, are deeply oneiric.

Contemporary Surrealism is an infinite source of amazing artists who feature the world of the unconscious in numerous and mesmerizing ways, among them noteworthy, just to mention a few: Andrea Kowch, Timothy Cummings, Aron Wiesenfeld, Mike Worrall, Renata Palubinskas, Rodney Wood, Shinji Asano, Simona Bramati, Alessandro Bulgarini, Scott Hess, Eddy Stevens, Michaël Borremans, Jolanda Richter, Guy Kinnear, Pamela Wilson, Steve Da Luz, Michael Pearce, Graham Toms, Salvatore Alessi, Ilaria del Monte, and Nojus Petrauskas ${ }^{5}$. These painters, through paintings, dig into the deepest sides of the unconscious.

\section{Main Divergences between Early and Contemporary Surrealists}

Even though today's painters are still involved in decoding the mysteries of the unconscious, albeit, in another way (which will be analyzed shortly), two main differences separate the two groups.

The first dissimilarity makes reference to politics and the second to psychology.

\footnotetext{
4 See: http://www.luciogiuliodori.net/steven-kenny-sinterview.html, retrieved December 04, 2018.

They are all living artists.
} 
The first Surrealists were fascinated by Marxists theories and, at least at the beginning, tried to add a Marxist tone to their narrative, here is what Breton (1935) stated about it: "Transformer le monde, a dit Marx; "Changer la vie", a dit Rimbaud; ces deux mots d'ordre pour nous n'en font qu'un'. This famous statement by André Breton underscores the surrealists' view about Communism.

To this regard, Robert Short (1966) affirmed:

"Not that the Surrealists ever had a decisive effect on the course of political events, or made any original contribution to political theory. The interest of the movement's political history lies in its tenacious efforts, set forth in some highly articulate polemical writing, to associate its intellectual, artistic, and moral preoccupations with the aims and methods of international communism. The issues at stake may be reduced to three: the reconciliation of a generalized spirit of revolt with revolutionary action; the reconciliation of the idea of a "spiritual revolution" and its accompanying insistence on ethical "purity" with the practical necessities of political effectiveness; the reconciliation of an independent revolutionary art with the demands for propaganda and didacticism made by the communist party" (p. 17).

Contrariwise, contemporary artists are very far from Marxism and Communism, for the historical context changed drastically. As a matter of fact, the faith in Communism, through the last decades, decreased enormously and not only among Surrealists: the soviet tanks in Prague and Budapest, the gulags, the estimated twenty million people killed in total and, in the end, all the Stalinist terror unveiled by Khrushchev wellnigh thawed out even the strongest believers.
Today, Surrealism is everything except a politicized movement, even less a communist or Marxist movement. To this regard, we should look at this fact as an amazing achievement indeed: the noble search of the inner world and the unconscious has nothing whatever to do with Communism.

If in political terms there's not even comparison, a similar clash doesn't apply psychologically. Nowadays, the majority of painters don't experiment with techniques anymore as the first Surrealists did; nevertheless, what they paint is unequivocally related to the unconscious. They don't experiment anymore ${ }^{6}$ as, again, the historical context changed: the unconscious is not a brand new concept anymore, at least as it was at the beginning of the 20th century when Freud's theories spread ${ }^{7}$.

The great part of contemporary painters relates to the unconscious in the way it best fits them: only painting indeed. They are still fascinated by the riddles that the concept of the unconscious rises, and they still paint oneiric subjects, world-dreams scenarios are still central in their work yet their involvement is, generally, limited to painting (with certain exceptions: Dino Valls for example).

Nowadays, there is no Manifesto, no guidance to share, that is why artists don't belong to a specific closed group. They are absolutely free in their commitment. However, they do represent the heritage of the movement created by Breton in 1920 .

To sum up, even though that specific movement died, there are still artists today in-

6 They don't because the first Surrealists tried quite a wide range of techniques which, in the end, didn't yield significant results in terms of an ultimate definition of the unconscious.

7 It 1920 the American psychologist G. Stanley Hall invited Freud to visit Clark University in Worcester, Massachusetts, to deliver a series of lectures. 
volved in depicting the contents of the unconscious, and they do so in different ways. Whether calling them Surrealists or not is still an unsolved question, it is as fascinating as hard to tackle.

As long as we still haven't reached an objective definition of the unconscious itself - for science hasn't found it yet ${ }^{8}$ - we shouldn't consider the surrealist chapter as closed for good. As scientists and artist are still facing up to its mysterious nature, we - yet being acknowledged of their history - should probably keep calling them Surrealists, contemporary Surrealists.

\section{Dino Valls}

Within the various and jagged context of Contemporary Surrealism, the Spanish contemporary painter Dino Valls stands out as a beautiful exception.

In the Vallsian output, painting is a synonym of inner investigation for what he does is literally "psychoanalysis through art". Let us consider his words:

\section{"The figures I paint are incarnations of} the subconscious-projection of my soul. Just like a psycho-analyst-easel. There, psychoanalysis walls and mirrors of the collective unconscious are exposed. Sciences and religions claim to explain the eternal question of the meaning of existence, the profound dichotomy between the material and the spiritual. Art must unite this duality; its realm is the space between one and the other" (Trabacchini, 2010) ${ }^{9}$.

\footnotetext{
Psychology has struggled with it over the past decades and, needless to say, a breakthrough in finding new answers is still yet to come. To deepen the matter see the famous and detailed work by Ellenberger, 1970.

9 I have also delved deeper the issue on this short article on my website: http://www.luciogiuliodori.net/noteson-surrealism-.html, as well as in other four essays
}

Valls undoubtedly assigns art a hard undertaking. However, what matters here is his conception of art and his way of being an artist: "A psycho-analyst-easel".

Valls uses a Jungian technique called "active imagination" through which he manages to see the contents of his unconscious which provides the material he would then paint. This technique was very important for Jung's psychotherapy:

"In his final great work Mysterium conjunctionis, he shows how active imagination is the way to self-knowledge ("Know thyself"), and the process of individuation. From his mature perspective, he is describing much more than a specific meditative procedure or expressive technique. In the deepest sense active imagination is the essential, inner-directed symbolic attitude that is at the core of psychological development" (Chodorow, 1997, p. 17).

This famous technique should be performed keeping the conscious mind awake; it could be described as a kind of "contemplation" where conscious and unconscious literally meet - it goes without saying that we are extremely far from the early surrealist techniques where only the unconscious mind was involved while the conscious was totally rejected.

"Jung speaks of the need for systematic exercises to eliminate critical attention and produce a vacuum in consciousness. This part of the exercises is familiar to many psychological approaches and forms of meditation. It involves a suspension of our rational critical faculties in order to give free rein to fantasy.

The special way of looking that brings things alive (betracheten) would be relat-

partly published on my Academia.edu page: https://rudn.academia.edu/LucioGiuliodori. 
ed to this phase of active imagination. In

his Commentary on The Secret of the Golden Flower (1929) Jung speaks of the first step in terms of wu wei that is, the Taoist idea of letting things happen" (Chodorow, 1997, p. 10).

Valls then could be considered as the coryphaeus of this new generation of surrealists painters which are characterized by this mix between innovation and heritage ${ }^{10}$.

By innovation, I refer to overcoming the strict rules exposed by Breton, especially those relating to the rejection of the conscious mind, while by heritage I make reference to a kind of fidelity to the surrealist core itself: the depiction of the unconscious - it is self-evident that the depiction must be preceded by some sort of investigation which nowadays totally differs from the early Surrealism's.

\section{Conclusion}

André Masson, echoing Jung, once described Surrealism as a collective experience of individualism. Jung himself, stated that "the unconscious manifests itself through images" (Jung, 2009), hence dreaming is a perfect tool of individual investigation for surrealist artists whose main task is painting.

Moreover, the more an artist connects with the unconscious, the stronger the connection becomes. The reproduction itself is not only art - as Hans Arp puts it: "We do not want to reproduce, we want to produce, like a plant which produces a fruit" (Paldam, 2015, p. 97).

10 To this regard see my essay: In search of the Self, through paintings-beyond paintings: Dino Valls. Proceedings of the Conference: How and where are we going?, Finance University, Faculty of Philosophy, Moscow. Retrieved May 17, 2019, from: https://www.academia.edu/39176029/In_search of the SS elf through paintings-beyond paintings Dino Valls.
In conclusion, surrealist painters by incessantly glimpsing and reproducing the unconscious, become familiar with the recesses of it. They manage to have a symbiosis with their inner world, as they break down, step by step, the barriers that separate the conscious and the unconscious.

Therefore, surrealist painting is a sophisticated exercise of interaction with the unconscious, which in turn is not merely a source of creativity and inspiration, but rather an indicator of what lies behind the conscious wall. Surrealist art unveils a marvellous invisible world, which, amid archetypes and shadows, lives within.

\section{REFERENCES}

Adonis (2016). Sufism and Surrealism. London: Saqi Books.

Assagioli, R. (1993). Psicosintesi. Roma: Astrolabio.

Bradley, F. (1997). Surrealism. London: Tate Publishing.

Breton, A. (1935). Position Politique Du Surréalisme. Paris: Sagittaire.

Breton, A. (1969). Manifestoes of Surrealism (R. Seaver \& H. R. Lane, Trans.). Ann Arbor: The University of Michigan Press.

Caws, M. A. (2010). Surrealism. Abridged: Phaidon Press.

Chodorow, J. (1997). Introduction to Jung on Active Imagination. Princeton: Princeton University Press.

Eimert, D. (2013). Art of the $20^{\text {th }}$ Century. New York: Parkstone.

Ellenberger, H. (1970). The Discovery of the Unconscious: The History and Evolution of Dynamic Psychiatry. New York: Basic Books. 
Gualdoni, F. (2008). Surrealism (Ch. Evans, Trans.). Milano: Skiria.

Jung, C. G. (2009). The Red Book. New York: W. W. Norton \& Company.

Nadeau, M. (1989). The History of Surrealism. Harward: Belknapp Press.

Paldam, C. S. (2015). Art, Technology and Nature: Renaissance to Postmodernity. Routledge: London.

Recalcati, M. (2007). Elogio dell'inconscio. Milano: Bruno Mondadori Carl Gustav.
Short, R. S. (1966). The Politics of Surrealism. Journal of Contemporary History, 1(2), 3-25.

Teodorani, M. (2011). Sincronicità. ll Legame Tra Fisica e Psiche da Pauli e Jung a Chopra, Cesena: Macro Edizioni.

Trabacchini, A. (2010). Tele pazze per l'uomo saggio. Intervista a Dino Valls. Retrieved April 03, 2020, from: http://telepazze.blogspot.com/2010/04/intervista-dino-valls.html. 